\title{
Memory and politics: "totalitarian" and "revisionist" approaches to the study of the Holocaust in Hungary and Slovakia ${ }^{1}$
}

\author{
doc. Dr. Eszter BARTHA, M.A., PhD. \\ doc. PhDr. Slávka OTČENÁŠOVÁ, M.A., PhD.
}

\begin{abstract}
The totalitarian theory, which essentially treats Stalinism and Nazism (in a wider variant Communism and Fascism) as equally evil regimes, or at best, fundamentally the same arch-enemies of democracy, has been challenged by the so called revisionist school in the Anglo-American academy already from the 1980s. The theory, however, experiences a new Renaissance in the Eastern and East-Central European postsocialist countries, where it is used to de-legitimate and criminalize the state socialist past.

The paper examines the politics of memory and the impact of new theoretical currents on the Holocaust research in the two selected countries, Hungary and Slovakia. We argue that while Holocaust was effectively silenced in the official discourse under the state socialist era, after 1989 there have been considerable efforts to integrate the tragic chapter of the Holocaust in the national historical consciousness. However, in the far right-wing discourses the Holocaust and the responsibility of the local elites for the persecution and deportation of the Jews is often relativized if not denied. We can illustrate this point with a Hungarian example. Recent historical studies demonstrated that in World War II (WWII) the Hungarian army, which was sent to the territory of today's Ukraine to exercise military control over the occupied territories, participated in the mass murder of the local Jews and the terrorization of the population. These studies and documentation triggered a fierce debate among historians, who argued that the documentation was based on Soviet "falsification" and it is an attack against Hungarian national consciousness and other scholars, who claimed that the clarification of the past should be part of the national historical consciousness.

The paper introduces some major historical debates in Hungary and Slovakia, which illustrate the ideological and political struggle between the supporters of the neo-totalitarian paradigm and the "revisionists" (who seek to go beyond the totalitarian simplifications). The latter also advocate the respect of the sources - with the opening of the archives the documents are accessible to any interested researchers and there have been extensive oral history projects conducted in the region. Diaries, letters and other ego documents can also help the work of a committed historian. Indeed, with the opening of the archives

1 The paper is the outcome of the project VEGA MŠVVaŠ no. 1/0254/17. Eszter Bartha was also supported by the International Visegrad Fund.
\end{abstract}


"revisionists" prefer to speak of a new era, which they call post-totalitarian, indicating the end of Cold War propaganda - on both sides. However, it seems that the former "East" (still) remains a terrain of ideological debates. In the paper we demonstrate how the contested ideological terrain of the interpretation of "Communism" is linked to the rise of a new anti-Semitism in both Hungary and Slovakia. In order to combat with this, it is essential to go beyond national sensitivities and national traumas (which is often translated as 'we have suffered a lot, too') and understand our common history from a global point of view.

\section{Keywords}

totalitarian theory, "revisionism", relativization of the Holocaust, genocide in the Soviet Union, Holocaust studies in Hungary and Slovakia

\section{Introduction: totalitarianism and the Holocaust}

"Today there is no common knowledge: Power and the politics of memory - is there an alternative?"2 - this is the title of a recent interview conducted with Tamás Krausz, Professor of Eötvös Loránd University of Budapest, whose book entitled Reconstructing Lenin: An Intellectual Biography (also published in Russian) won the Isaac Deutscher Memorial Prize 2015. ${ }^{3}$ As the professor explains in the interview, with the title he sought to refer to the post-1989 politics of memory in the East-Central European countries including Hungary, where there have been systematic attempts to eradicate the $20^{\text {th }}$ century history of the region as it was taught before the change of regimes and re-interpret the past century according to the legitimating needs of the new elite. The interpretation of the WWII has become a particularly heavily politicized issue because the history of state socialism in Eastern Europe is inseparable from the "zero hour" - namely, 1945 and the victory of the Allied over the Nazi Germany. As East-Central European countries such as Hungary seek to "whitewash" the postwar right-wing regimes, whose social and intellectual tradition they claim to continue, there has been government-led attempts to mitigate the responsibility of the contemporary elite for the alliance with the Nazi Germany and the attack of the Soviet Union. This historical endeavour goes so far as if some Hungarian historians - as the professor puts it - would like to win the WWII in retrospect. The attempt to "whitewash" the Hungarian elite for the participation in a genocide in the Soviet Union ${ }^{4}$ and the assistance in the Holocaust goes hand in hand with the demonization of Communism and the Red Army. Some "historians" even come up with the argument that Hitler only fought a "preventive" war against the Soviet Union - hopefully they are not aware of the fact that this has been a major claim in the Goebbelsian propaganda.

In what follows we seek to give a critique of the totalitarian theory, which has become a mainstream paradigm in East-Central Europe after the collapse of state socialism. We will

2 BARTHA, Eszter: Ma már nincsenek evidenciák...Hatalom és emlékezetpolitika - van-e alternatíva? Interjú Krausz Tamással, in: Kritika, 46, 2016, November-December, 10-13.

3 KRAUSZ, Tamás: Reconstructing Lenin: An Intellectual Biography, New York 2015.

4 The barbarism of the Hungarian army in the Soviet Union is well documented in a book, which received a very controversial reception in Hungary: KRAUSZ, Tamás - VARGA, Éva Mária (eds.): A magyar megszálló csapatok a Szovjetunióban. Levéltári dokumentumok 1941-1947, Budapest 2013. On the reception of the book see: GÉMESI, Ferenc (ed.): A magyar megszállás-vajúdó nemzeti önismeret: válasz a kritikákra, Budapest 2013. 
show in what ways this paradigm is used to retrieve the national elite groups of the responsibility for participating in the Holocaust. We will follow - on the example of Slovakia - the political changes, which triggered the re-interpretation (and sometimes the re-invention) of national history. We chose Slovakia as a "full" case study because it belongs to the new states, which have been established after the change of regimes: here postsocialist transformation went hand in hand with a new nation-building project. Lastly, we will introduce a major historian debate, which emerged following the publication of the documentation of the atrocities and war crimes the Hungarian army committed in the Soviet Union. ${ }^{5}$

The totalitarian theory, which essentially treats Stalinism and Nazism (in a wider variant Communism and Fascism) as equally evil regimes, or at best, fundamentally the same arch-enemies of democracy, has been challenged by the so-called revisionist school in the Anglo-American academy already from the 1980s. ${ }^{6}$ The theory, however, experiences a new Renaissance in the Eastern European postsocialist countries, where it is used to de-legitimate and criminalize the state socialist past.

Stefan Troebst distinguishes between four groups of ex-socialist countries on the grounds of their relation to the old and new regimes. The first group includes countries, which categorically distance themselves from the past, and consider Communist regimes as ethnically alien phenomena. Such countries are Estonia, Latvia, Lithuania and Croatia where the Yugoslavian model is held to be 'Serbian Communism'. In the second group of countries there is no national consensus of state socialism and the interpretation of the past regime remains a contested terrain (and often ideological battlefield). Troebst mentions here the controversial reception of the House of Terror in Hungary, but he also considers Poland, the Czech Republic, Slovakia, Slovenia and Ukraine as part of this group. The countries of the third group hold state socialism to be alien from the national character but they recognize the modernization attempts of the past regime: Bulgaria, Romania, Albania, Macedonia and Serbia-Montenegro. Lastly, in the fourth group there was no elite change and the old autocratic structures survived. Troebst lists here the majority of the ex-Soviet republics. ${ }^{7}$

Troebst's classification can be criticized but it gives us a basic idea of the relationship between the interpretation of state socialism and the recognition of the responsibility of the contemporary national elites for the Holocaust and the war crimes their armies committed in the Soviet Union. Most countries in the region chose the totalitarian theory, which assumes an essential similarity between Nazism and Stalinism as if these two regimes would be equally evil (and some historians even assume that Nazism represented the "smaller" evil in this contest). It is therefore worth pointing out that totalitarianism was essentially a Cold War ideology, and it was always propaganda rather than an academic theory. In

5 KRAUSZ - VARGA.

6 On the "promotion" of totalitarianism in the Anglo-Saxon sovietology see: FITZPATRICK, Sheila: Revisionism in Soviet History, in: History and Theory, 46, 2007, 4, 77-91; LYNNE, Viola: The Cold War in American Soviet Historiography and the End of the Soviet Union, in: The Russian Review, 61, 2002, 1, 25-34. For a critical discussion of totalitarianism see also: FITZPATRICK, Sheila - GEYER, Michael (eds.): Beyond Totalitarianism: Stalinism and Nazism Compared, New York 2009. See also: KRAUSZ, Tamás: A Gulag aktualitása, in: Gulag: A szovjet táborrendszer története, KRAUSZ, Tamás (ed.), Budapest 2001, 13-26; BARTHA, Eszter: A sztálinizmus a régi és új historiográfiában: A jelenség meghatározásának elméleti és módszertani problémái, in: A sztálinizmus hétköznapjai: tanulmányok és dokumentumok a Sztálin-korszak történetéből, KRAUSZ, Tamás (ed.), Budapest 2003, 15-39.

7 TROEBST, Stefan: Holodomor oder Holocaust?, in: FAZ, 2005, 152, 4 July. 
the Anglo-American world Abbott Gleason wrote a remarkable book entitled Totalitarianism: The Inner History of the Cold War, ${ }^{8}$ in which he documented how closely the CIA co-operated with the American academy in order to promote totalitarianism and ensure that the field remains dominated by committed anti-Communists. The situation changed in the 1970s when the Vietnam war and the left-wing intellectual climate of the 1960s challenged totalitarianism and "revisionist" scholars (the name refers to their endeavor to "revise" the totalitarian theory) showed that the model fell short to explain the functioning of Soviet society - even at the time of the "Great Terror". ${ }^{9}$ In the 1980s the totalitarian theory has become a discredited paradigm in the Anglo-Saxon academic world - at least among the progressive circles. This has changed again, with the collapse of state socialism and the end of the Soviet Union - but that has become part of the politics of contemporary memory.

The origins of the totalitarian theory go back to the 1930s. It was first used by Paul Tillich, who escaped from the Nazi Germany, and who thought that the state had become omnipotent in both Germany and the Soviet Union. ${ }^{10}$ It should be noted that in England and in the United States Hitler's rise to power did not trigger immediately the protest of the intellectuals even though they were aware of the fact that Hitler had been destroying the democratic institutions. In England Christian circles started to worry, who thought that the new totalitarianism poses a threat to the religion and the Christian churches. ${ }^{11}$ "Dissident" left-wing circles, mainly the followers of Trotsky, would also draw a parallel between the Nazi and the Stalinist regimes on the basis of the show trials. ${ }^{12}$

The Molotov-Ribbentrop pact started a new phase in the history of totalitarianism. Even though Trotsky predicted that Stalin would be able - or would feel compelled - to sign the treaty, many Russian Mensheviks refused to believe this and reacted very emotionally. Even Rudolf Hilferding referred to the Soviet Union as a totalitarian state after this and Max Eastman, the translator of Trotsky's famous critique of Stalinism, ${ }^{13}$ wrote that no one can serve democracy and totalitarianism at the same time. ${ }^{14}$

There is no evidence that after the Nazi attack on the Soviet Union totalitarianism would interest many people in the Anglo-Saxon world. This situation changed with the outbreak of the Cold War when an intellectual "munition" was also needed to fight against the (suspected) Communist influence. The intellectually most outstanding work is undoubtedly Hannah Arendt's Origins of Totalitarianism, which was published in 1951, which sought to explain the rise of totalitarianism from a historical perspective. It is not easy to determine when Arendt started to write the book because the main themes - imperialism, anti-Semitism and the formation of the nation states - kept her mind busy since the 1930s. Her original aim was to explain the rise of Nazism in Germany, and it was only after the

8 GLEASON, Abbott: Totalitarianism: The Inner History of the Cold War, New York - Oxford 1995.

9 For a challenging interpretation of the working of terror in Stalinist Russia see: GETTY, J. Arch: Origins of the Great Purges: The Soviet Communist Party Reconsidered 1933-1938, Cambridge 1985; THURSTON, Robert: Life and Terror in Stalin's Russia 1934-1941, New Haven 1996.

10 GLEASON, 37.

11 Ibidem, 38.

12 See e.g. the articles of The Partisan Review, whose leading figure was Trotsky until his murder.

13 TROTSKY, Leon: The Revolution Betrayed. What is the Soviet Union and Where is It Going?, New York 1937.

14 GLEASON, 47. 
WWII when she first read about the Gulag that she decided to "include" Stalinist Russia in her book. She thought that the institutionalized and systematic terror as embodied in the concentration camps constitutes the basic "link" between the two regimes. ${ }^{15}$

The comparison between the Gulag and Auschwitz is particularly "helpful" to criminalize the history of state socialism - and in a wider sense, the whole Marxist concept of Communism. At this place we would like to single out only three important aspects, which need to warn us against the "easy" analogy. The first and most important aspect is the questioning of Auschwitz's singularity although this singularity has a voluminous literature. The Nazis planned and prepared the genocide intentionally, with large industrial methods, and the execution of their program was carried out in parallel with the unfolding of the totalitarian war against the Soviet Union - a war, which was started by the Dritte Reich. We should not forget that the totalitarian war fit in well with the original aims of the Nazis (colonizing the Slavic people, robbing them of their resources and the elimination of the European Jews at any price). It cannot be our aim to "whitewash" the Gulag but in the Soviet Union one cannot document the intention of a genocide - even though some Ukrainian "historians" are trying to interpret the great famine after the collectivization as a conscious "genocide" against the Ukrainian people ("Holodomor"). ${ }^{16}$

The second aspect is the relativization of Auschwitz. Many ex-socialist countries seek to identify themselves as both the victims of Nazism and Communism - although part of their population was actively co-operating with the Nazis and participated in the Holocaust. The totalitarian paradigm is often used in these countries in order to relieve national consciousness of facing the dark chapters of its history. The interwar period of Hungary was identified with the Horthy regime, which eventually led Hungary to the war and was responsible for the deportation of hundreds of thousands of Jewish people (the Jewry of the countryside) to the death camp of Auschwitz. This can be partly explained through the fact that the local elite committed itself to the revision of the Trianon Treaty, which largely narrowed the scope of the Hungarian foreign policy and eventually led to an alliance with Nazi Germany, which supported Hungary's quest for regaining the territories lost after the Trianon Treaty and expand the borders of Hungary. However, anti-Semitism was strong even in the interwar period with Hungary "pioneering" anti-Semitic measures with the numerus clauses, which set a certain ratio for Jewish students, who were allowed to be admitted to the universities. Furthermore, the local elite sought to finance the solution of social problems (poverty of the landless peasantry, bad housing conditions, lack of social security) and the implementation of other welfare program through the dispossession of Jewish people in Hungary. ${ }^{17}$ This politics was manifest even prior to Hungary's entrance to the war.

The third criticism concerns the interpretation of the terror. While the concept of terror is central for the totalitarian theory, it is unclear, what we mean by that - apart from the illustrative analogy with the death camps. ${ }^{18}$ A "revisionist", Wendy Z. Goldman wrote an excellent and thoroughly researched book, in which she showed that terror was in fact a common social "product" of the masses and the party elite: in fact, the latter frequently

15 ARENDT, Hannah: The Concentration Camps, in: The Partisan Review, 15, 1948, 7, 747.

16 For the background of this interpretation see: KRAUSZ, A Gulag aktualitása.

17 On the long-term policy of the robbing of the Hungarian Jews of all their property (and eventually of their life) see: ALY, Götz - GERLACH, Christian: Az utolsó fejezet: A magyar zsidók legyilkolása, Budapest 2005.

18 The literature strictly distinguishes between concentration camps and death camps. 
fell victim to the denunciations that the Party encouraged. ${ }^{19}$ Her important thesis is that the terror went hand in hand with a process of democratization: workers were "invited" to denounce the managers, who were charged with sabotage. Stalinist terror - no matter what we think of it - was a highly complex social phenomenon - whereas the extermination of the Jews "merely" followed from the Nazi racist theory.

\section{Re-writing national histories: the case of Slovakia}

The interpretation of Holocaust - after the Soviet "export" of Stalinism to East-Central Europe - was determined by the development of the Soviet political-ideological line. After the war the official Soviet propaganda silenced Holocaust with the reasoning that the "special" treatment of one ethnic minority (Jews count in Russia as an ethnic minority) would insult other minorities, and would be therefore harmful for the unity of the Soviet Union. ${ }^{20}$ In East-Central Europe there was also a fear that a too harsh retaliation and the condemnation of the past regime for the tragedy of the Jewry would render it more difficult to gain social support and legitimacy for the new, Communist state. Even though the Jewish Antifascist Committee put together the Black Book, documenting the genocide against the Jewish people in the occupied territories of the Soviet Union, the book could have only been published in the United States in 1946. ${ }^{21}$ The Jewish Antifascist Committee was eventually banned and many of its leaders were arrested. Holocaust could have returned as a topic only in the period of thaw under Khrushchev, and it was mainly a topic in literature and cinematography. In history it remained a political taboo. Holocaust has not disappeared from the Soviet collective memory; officially, however, the Jewish tragedy lost its ethnical character: all victims were represented as victims of Fascism or partisans.

The silencing of Holocaust relieved the national collective memories of the East European countries of facing and coping with their Fascist past. While it is true that the genocide would have been impossible without the Nazi program of the annihilation of Jewry, and the infrastructure provided, it is also true that that Nazi troops received an active support from certain segments of the local population and authorities in Eastern Europe (including Slovakia). This could not be adequately studied and discussed under state socialism because anti-Semitism was understood as a political question. All Eastern European countries held themselves to be the victims of Fascism and this collective memory failed to encompass the specific Jewish tragedy and the public acknowledgement that parts of the local elite actively participated in the Holocaust.

After WWII Czechoslovakia followed the "Eastern" path. Until the change of the regime at the end of the 1980s, the topic of the Holocaust was considerably silenced in Slovakia, for the same reason as in Hungary: the newly established Communist regimes thought that a confrontation with the fascist past could again stir up anti-Semitic sentiments and weaken the legitimacy of the Communist Party.

Historical research and historiography were under the control of the Communist Party,

19 GOLDMAN, Wendy Z.: Inventing the Enemy: Denunciation and Terror in Stalin's Russia, Cambridge 2011.

20 KRAUSZ, Tamás: The Soviet and Hungarian Holocausts: A Comparative Essay, Boulder (Colorado) 2006.

21 The book was published in Hungarian in the edition of KRAUSZ, Tamás (ed.): Az ismeretlen fekete könyv, Budapest 2005. 
and especially the years which followed the Prague Spring of 1968 were marked by strong ideological pressure, party censorship, and self-censorship in each sphere of public life, including historical research and historiographical production. But even in the 1960s, which were characteristic by less oppressive relations between the state authorities and the public, studies on the Holocaust could only be published if they concurrently included a sturdy antifascist rhetoric within a class struggle paradigm and excluded sensitive references to Slovak nationalism. ${ }^{22}$ The years 1989 and 1993 brought significant changes to Slovak society. The transition from one political regime to another, which started in 1989, and the dissolution of Czechoslovakia followed by the establishment of the Slovak Republic in 1993, encouraged the reassessment of the past and opened space for new interpretations of history. On the one hand, the development of political, methodological and institutional pluralism in Slovak historiography after 1989 opened possibilities for systematic research on topics which had been before neglected. One of such topic was the history of the Holocaust - its research and interpretation has been experiencing a significant revival in Slovakia since the 1990s. Focusing firstly on political history and archival documents, historians have published a number of high quality monographs, collections of papers, editions of documents and articles. ${ }^{23}$ Secondly, a very important step was launched by the ethnologists in Slovakia, soon followed by sociologists, historians and other scholars - exploring the so-called small history of the Holocaust, i.e. collecting, preserving, analyzing, interpreting and making accessible the testimonies of its survivors and their contemporaries. ${ }^{24}$ The outcomes of solid interdisciplinary research have been also communicated to a broad public through media and school education. ${ }^{25}$ The contemporary state educational program explicitly addresses the Holocaust as one of the mandatory topics of the history education at elementary and high schools, and explaining and documenting the topic of the Holocaust on a concrete example is a compulsory performance standard expected from pupils and students. ${ }^{26}$ The artistic production related to the topic of the Holocaust has been rather vivid, even prior to 1989 , when it was often substituting censored scholarly production. ${ }^{27}$

22 PAULOVIČOVÁ, Nina: The "UmasterablePast"? The Reception of the Holocaust in Postcommunist Slovakia, in: Bringing the Dark Past to Light: The Reception of the Holocaust in Post-Communist Europe, MICHLIC, Joanna - HIMKA, John-Paul (eds.), Lincoln 2013, 549-590.

23 For an account of the historiographical production on the Holocaust published in Slovakia during the 1990s see NIŽŇANSKÝ, Eduard: Slovenská historiografia v 90. rokoch 20. storočia o holokauste, in Historický časopis, $52,2004,2,317-330$.

24 Oral history and biographical narrative approach to study of the Holocaust has been well explored in Slovakia. It began with the project carried out in the cooperation with Yale University Fates of Those Who Survived the Holocaust, VRZGULOVÁ, Monika (ed.): We saw the Holocaust, Bratislava 2002, and continued with a number of different case studies and articles since then. From the most recent works see VRZGULOVÁ, Monika: Nevyrozprávané susedské histórie, Bratislava 2017 and PEKÁR, Martin: Príbeh Juraja Szánta. Rozhovor o záchrancoch a obeti, Košice 2018.

25 Apart from the formal education and official history textbooks, the topic of the Holocaust has been presented in different didactical materials published by various institutions (Milan Šimečka Foundation, Open Society Foundation, Museum of Jewish culture, Sered' Holocaust Museum, different regional didactical centers, etc.).

26 Online: http://www.statpedu.sk/files/articles/dokumenty/inovovany-statny-vzdelavaci-program/dejepis_ nsv_2014.pdf (Downloaded 16 October 2017).

27 KAMENEC, Ivan: Fenomén holokaustu v historiografii, v umeleckej tvorbe a vo vedomí slovenskej spoločnosti, in: Holokaust ako historický a morálny problém v minulosti a v súčasnosti, Bratislava 2008, 111-117. 
Since 2006 the denial of the Holocaust is defined as a criminal act by the law in Slovakia. ${ }^{28}$ On the other hand, however, it is important to add that since the establishment of the Slovak republic in 1993, some part of the political elites demanded the reconstruction of the national past in line with the rising nationalism and isolationism of the first half of the 1990s, and sought those presentations of Slovak history that were believed to legitimize the newly established state. This led to a search for examples from the past which would somehow emphasize Slovakia's tradition of independence. Focusing on what was unique and exclusive in Slovak history often went hand in hand with the creation or revival of historical myths as well as the negative stereotyping of others. ${ }^{29}$ In this context, it is necessary to mention the new interpretations of WWII in Slovak historiography that have emerged since 1993. Prior to the change of regime in 1989, the official communist historiography focused mainly on the topic of the Slovak national uprising as the main event of the war, which was depicted as a vigorous and successful national resistance, and its anti-fascist character was emphasized. While the diversification of the historical research within the topic of WWII is certainly welcomed and has brought about a lot of valuable outcomes, there are also visible certain efforts to rehabilitate the WWII Slovak state. Interpreting it as a solely positive period in Slovak history, as a source of the tradition of statehood and public commemorating of its heritage have gone hand in hand with the relativization of the Holocaust and its consequences in Slovakia. Glorification of the WWII Slovak state is not uncommon among professional historians (drawing from the tradition of the émigré historiography), and as such it is often accompanied by deliberated forgetting about the traumatic events that had a fatal impact on a considerable part of the population. One of the most vigorous discussions in Slovak historiography after the establishment of the Slovak Republic in 1993 was a reaction of the mainstream historical community centered around the Historical Institute of the Slovak Academy of Sciences, backed by the Slovak Union of Anti-Fascist Fighters and by representatives of the Jewish community living in Slovakia on the history textbook written by Milan Stanislav Durica, which was declared by them to as a work glorifying the WWII Slovak state and spreading a negative image of the Other, mainly of Hungarians, Czechs, Jews, and non-Catholics in general. ${ }^{30}$ On the other hand, nationally-oriented sec-

28 Section 422d of the Criminal Law no. 300/2005 of the Code "Who publicly denies, questions, doubts or approves of or tries to defend the Holocaust, the crimes of the regime based on fascist ideology, the crimes of the regime based on the communist ideology or crimes of a different similar movement, which by violence, threat of violence or threat of heavy harm aims towards repressing of fundamental rights and freedoms of persons, shall be punished by imprisonment in the duration of six months to three years." Online: http://www.zakonypreludi.sk/ zz/2005-300 (Downloaded 5 November 2017).

29 One of the first challenging of modern nationalist Slovak myths had its origins in the artistic production of the so-called Generation 1909 (especially in the works of Cyprian Majerník and Ján Želibský). These painters approached the heroizing and monumentalizing images of Slovak village and peasantry which had been established in the works of Martin Benka, Ján Hála, Štefan Polkoráb, etc. in an ironical manner. It was no coincidence that the members of the Generation 1909 were also reflecting war terror of WWII. They created not only visual report about executions and refugees, but their artistic approach implicitly linked sentimental heroization of Slovak village and dangerous autonomist efforts in interwar Slovakia and Slovak autonomy during WWII: MIGAŠOVÁ, Jana: Ironická naivnost medzivojnových obrazov Generácie 1909, in: Kapitoly k dejinám estetiky na Slovensku V, Prešov 2013, 140-166.

30 The Response of Slovak Historians to M. S. Durica's book: A History of Slovakia and the Slovaks', originally published in the Práca daily, 19 April 1997, English version online: http://www.angelfire.com/hi/xcampaign/praca. html (Downloaded 20 November 2017). 
tors of the public and certain such-minded institutions, as well as the Ministry of Education, the Slovak National Party and some Catholic circles, were defending the book and the interpretation of the past which it provided. The Ministry of Education, which was in the hands of the Slovak National Party and which introduced the controversial textbook into school education without prior consultations with scholars, kept the authoritarian approach and disregarded any objections from protesting historians or representatives of the Jewish community, and did not take part in any constructive dialogue with any representatives from the scientific or educational communities. It was only after the intervention of European Union institutions abroad that the Slovak government reluctantly withdrew support from the publication's use in schools. During the past thirty years we have seen historians questioning whether Holocaust really happened in Slovakia ${ }^{31}$ and representatives of public life have repeatedly taken part in controversial events, such as promoting the commemoration of controversial historical figures related to the WWII Slovak state. ${ }^{32}$ The so-called Lex Hlinka, which was a campaign resulting in adopting the law affirming the importance of Andrej Hlinka for the Slovak nation and its statehood tradition, was also perceived with disappointment, reservations and open disagreement from the members of the Jewish community, since Andrej Hlinka is often perceived as a symbol of the Slovak fascist movement ${ }^{33}$. A complex study on how these messages communicated by certain political elites and by a part of the community of historians influence the general public needs to be conducted, however, some of research completed so far indicates that the feelings of anti-Semitism have been present among the population in Slovakia. ${ }^{34}$ This trend has been confirmed also in the recent Eurobarometer survey conducted by the European Commission, which demonstrated that fearing the Other is widespread in Slovakia. ${ }^{35}$ Despite of entering the $\mathrm{EU}$ and the general request for the implementation of the European values and tolerance, it is not rare that the political elites are encouraging the views openly promoting hostile approach to the Others, be it either minorities, or more recently immigrants and refugees. Although the reason for this situation has been ascribed to the recent economic and reffugee crises, negative responses to the Other are also partially a by-product of a longterm trend of ethnocentric and etatist messages communicated through some segments of school history education, certain media, some public spaces and also, in some cases, family education. Especially the youth is extremely vulnerable. Social networks have become influential tools in spreading all sorts of messages, often including hate speech, racist and xenophobic ideas and general excluding of the Other. An increasing number of cases of court cases with people, even $\mathrm{MPs}^{36}$, publicly spreading extremist anti-Semitic and anti-Roma messages, document the general situation in the present-day Slovak society. Formally, the measures have been adopted on the state level, which seemingly contribute to the eradication of anti-Semitism, yet the reality constantly proves to be different.

31 Online: https://domov.sme.sk/c/4812406/do-upn-chce-popierac-holokaustu.html (Downloaded 4 December 2017).

32 Online: https://www.holocaust.cz/zdroje/clanky-z-ros-chodese/ros-chodes-2000/duben-3/kauza-tisova-tabula/ (Downloaded 7 December 2017).

33 Online: http://www.epi.sk/zz/2007-531 (Downloaded 15 December 2017).

34 PAULOVIČOVÁ, 559.

35 Standard Eurobarometer 84. Autumn 2015. Public Opinion in the European Union. Published by the European Commission in December 2015.

36 Online: https://dennikn.sk/1132293/mizik-ma-vysvetlovat-na-sude-extremisticky-status-radsej-mlci/ (Downloaded 16 December 2017). 


\section{Fighting for a "heroic" past: the politics of memory in Hungary}

In the more liberal climate of the Kádár era in Hungary dissident writers already published about anti-Semitism in the samizdat journal Medvetánc in 1985. After the change of regimes it can be argued that the revival of the Holocaust studies went hand in hand with the rise of a new anti-Semitism. Economic re-structuring after 1989 effectively impoverished many people: in addition, according to the calculation of Mark Pittaway, more than $20 \%$ of the workplaces were lost. In this climate the reorganized far-right could win many new supporters.

While there has been an abundance of the Holocaust literature after 1989, the Hungarian far right wing party, Jobbik, became the second major political party at the 2018 parliamentary elections in Hungary. As Mark Pittaway concluded in The Oxford Handbook of Fascism, in which he wrote the part 'Fascism in Hungary': "Its past may be complicated but, at the time of writing [2009], the radical right seems likely to have a future." 37

The fact that Holocaust was silenced in the official discourse received a special emphasis after the collapse of state socialism when anti-Semitism was no longer a political taboo. However, it was not only the political-ideological control of the state, which ceased to exist but the whole history of the $20^{\text {th }}$ century was seen in a different light, which had an impact on the history of Holocaust. Modern history has become a contested terrain, and a new ideological battle started for the appropriation of the national collective memory and for the development of a new, "authentic" narrative in the place of the discredited Communist history. Unfortunately, sometimes political-ideological interests even today precede the academic considerations. What is at stake is not only the interpretation of Holocaust but also the whole history of state socialism. After the collapse of state socialism, totalitarianism and the equation of Communism and Fascism became a fashionable ideology in Eastern Europe. This comparison even goes so far that the atrocities committed in one regime serve as an "excuse" for the atrocities committed under the other one. This is how it was possible to hold Endre Ságvári (a Communist, who died in 1944 while fighting with the gendarmerie) responsible for the atrocities committed under the Rákosi regime (the Stalinist regime in Hungary). The attempt to demonize Communism is often linked with finding an "excuse" for Fascism as if the latter would have been less evil. ${ }^{38}$

Recent historical studies also shed light to another dark and largely forgotten chapter of Hungarian history. ${ }^{39}$ The Hungarian army, which was sent to the territory of today's Ukraine to exercise military control over the occupied territories, was engaged practically in a genocide against the local population. These studies and documentation triggered a fierce debate among historians, who argued that the documentation was based on Soviet "falsification" and it is an attack against Hungarian national consciousness and other scholars, who claimed that the clarification of the past should be part of the national historical consciousness.

Krausz's argument that the Hungarian army committed such atrocities that it can be described as "genocide" triggered fierce attacks against the professor. As he put it: "This

37 Republished in FÁBRY, Adam (ed.): From the Vanguard to the Margins: Workers in Hungary, 1939 to the Present. Selected Essays by Mark Pittaway, Leiden - Boston 2014, 275.

38 KRAUSZ, Tamás - BARTHA, Eszter (eds.): Holokauszt: Történelem és emlékezet, Budapest 2006; KRAUSZ, Tamás - BARTA, Tamás (eds.): Az antiszemitizmus történeti formái a cári birodalomban és a Szovjetunió területein, Budapest 2014.

39 KRAUSZ - VARGA. 
volume objectively proves that the Horthy-regime bears a direct political and historical responsibility for the death of several hundreds of thousand people. The regime was responsible for a genocide. This explains the attacks against the book because it cannot be reconciled with the new legitimating narrative of the regime after 2010." And we are back to the politics of memory where Krausz represents the old-fashioned view that there is still common knowledge and there are historical facts that cannot be debated. As Christian Hartmann, an expert on the history of the WWII argued: "I think that the documents are credible. The Hungarian soldiers took part in many operations, which ended in a genocide. [...] I think that the main motive of the atrocities was the aggressive and widespread anti-Semitism among the Hungarian soldiers." 40

The significance of the book Magyar megszálló csapatok a Szovjetunióban (The Hungarian occupation armies in the Soviet Union) extends the borders of Hungary and Hungarian historiography. Tamás Krausz was the first historian in Eastern Europe, who documented the crimes of non-German soldiers, who assisted the Nazis in the genocide at Soviet territories. Fortunately, there are some historians, who follow his lead in Hungary: we can mention Ákos Fóris, who came to the same conclusion using German and Hungarian documents. He could also prove that the Hungarian elite was well informed about the crimes committed in the Soviet Union: one report even mentioned the tragic evidence of the mass murder of children (hundreds of baby carriages left behind...). ${ }^{41}$ It is therefore simply not true that Hungary "fell" victim to the Nazi Germany - as contemporary right-wing interpretations suggest. It is also worth stressing that not even a single Hungarian soldier was punished for the mass rape of the local women and the murder of the Jews or the "simple" Soviet civilians by the Hungarian military courts - this further reinforces the shared responsibility of the power elite. This, however, is strongly denied in the contemporary, right-wing, "official" narrative - the best proof of this is the monument erected at Szabadság-tér, which also gives home to the monument of the Soviet victims. The "monument of the victims of the German occupation" as it is called, was widely criticized for its failure to demonstrate the complicity of the Hungarian authorities in the genocide; it in fact suggests that the country lost its independence and the Hungarian government therefore cannot be called into account - while the truth is that Horthy was governor during the time when the Jewry from the countryside was deported to Auschwitz, to a secure death.

While historians such as Krisztián Ungváry is critical of the present government, anti-Communism often puts them on the same platform in the judgment of the Soviet Union and the Red Army. As a loyal follower of the totalitarian theory, Ungváry often uses a double standard for the Western and the Soviet armies. While the Western soldiers are described as "heroes", who generously distribute chocolate among the local people, he never misses the opportunity to criminalize and demonize the soldiers of the Red Army. ${ }^{42}$ In his attempt to win the WWII in retrospect, he even overlooks the fact that the backbone of the Wehrmacht was broken by the Red Army at Stalingrad - but as we know, there is no more common knowledge. Many like Ungváry even choose to believe in the theory of the "preventive war" - even though even Anglo-Saxon historians clearly declare this theory to be false. ${ }^{43}$

40 Népszabadság, 12 January 2014. Heimer György interjúja.

41 FÓRIS, Ákos: "A zsidók agyonlövése a megszállt területeken köztudomású": Hírek a megszállt keleti területeken elkövetett tömeggyilkosságokról a magyar polgári szerveknél, in: Eszmélet, 29, 2017, 115, $201-211$.

42 UNGVÁRY, Krisztián: Üllő és simogatás között. Válasz Krausz Tamásnak, in: Századok, 148, 2014, 1, $229-233$.

43 ROBERTS, Geoffrey: Stalin's Wars: From World War to Cold War, 1939-1953, New Haven - London 2006. 
Furthermore, even though Ungváry recognizes that the Hungarian troops participated in - or at least "assisted" the Holocaust in the Soviet Union, he in fact relativizes the Holocaust with the argument that the Soviets were as "bad" - or even more "evil" than the Nazis because they "represented" a totalitarian state. ${ }^{44}$ It is sad that the old racist arguments return - this time in a liberal masque.

The criminalization of "Communism" goes hand in hand with attempts to "whitewash" the Horthy-regime, which bears responsibility for Hungary's entry to WWII and the deportation of the Jewry from the countryside. To cite the renowned labour historian, Mark Pittaway, in this respect, however: "if paramilitarism was one element of the interwar Hungarian political scene relevant to the later emergence of fascism, then anti-liberalism and the hegemony of national Christian ideas within the political culture of interwar Hungary constituted another. Such attitudes generated forms of political discourse that stressed the unified and eternal nature of the Hungarian nation, its fundamentally 'Christian' character and emphasized that political leaders had a duty to 'defend' Magyars from their 'alien' enemies. In turn, such opinions led to a growing interest in völkisch ideas of 'race' and 'racial defence' and their translation into a Hungarian context during the 1920s, inspiring political movements that stressed the apparent Turanian origins of Magyars which embedded themselves in radical right-wing rhetoric." 45 While Pittaway was not a Holocaust-researcher, his arguments are in line with those, who highlight this essential continuity between the ideologies of the 1920s and 1930 s - as it is also cannot be denied that the deportation of the Hungarian Jewry from the countryside occurred during the time when Horthy was (still) the governor of Hungary. On the basis of Pittaway's life work one can reconstruct $20^{\text {th }}$ century Hungarian social history. Weak liberal bourgeoisie, great agrarian poverty, an authoritarian regime, which sought for the revision of the Trianon treaty and supported a strictly "national Christian" ideology - these are the main characteristics of the interwar era. Anti-fascism and socialism promised panacea for the depressing poverty and political exclusion of many, the social and economic misery of the lower classes, and the anomalies of the Hungarian caste system inherited from the feudal order. Indeed, an unprecedented social mobility can be documented in the region, which did not only imply urbanization and extensive industrialization as peasants became workers but many peasants and workers were "uplifted" to the ranks of the intelligentsia and the nomenklatura. After the 1956 revolution workers received a real chance to become incorporated in the "middle class" - indeed, if not embourgoisement but "petty embourgoisement" can be observed in many working-class (and peasant) communities.

Many of these - however limited - social and economic results were lost after the change of regimes. The disappointment in the political left brought with itself the rejection of the left-wing alternatives to state socialism; and the lack of a strong trade union movement rendered any working-class resistance to privatization and neo-liberal policies illusory. The anger and frustration of the "little man" was channeled into the support of ring-wing populism. It remains to be a question whether there will be a (further) shift to this direction; but in any case, we can safely paraphrase the sad prognosis of Mark Pittaway: the radical right does have a future in Hungary.

44 UNGVÁRY, Krisztián: A Magyar megszálló csapatok a Szovjetunióban, 1941-1944: esemény, elbeszélés, utóélet, Budapest 2015. For a critique see: KRAUSZ, Tamás: "Úriember" megszállók és "jogtipró" partizánok? A magyar megszálló csapatok népirtó tevékenysége Ungváry értelmezésében, in: Eszmélet, 28, 2016, 109, 151173. See also GÉMESI.

45 FÁBRY, 261. 


\section{Conclusion}

As we have seen, the Hungarian and Slovakian histories and historiographies from 1939 both show remarkable similarities. During the war, the local elites and segments of the population actively or passively participated in the anti-Semitic measures, the persecution of the Jews, and eventually the deportations, which would have been practically impossible without the cooperation of the Hungarian and Slovakian authorities. If we compare anti-Semitic propaganda, we can also find remarkable similarities - the dispossession of the Jews was "embedded" in the political program of the right-wing political forces. This can be partly explained through the similar social structures: the national bourgeoisie in both countries were weak, and the bourgeois society and capitalist development were seen as "alien" or "Jewish" phenomena.

After WWII, Communist modernization promised panacea for the ills of capitalism in both countries. This era constitutes even today a much disputed terrain of historical debates and interpretations. We pointed out the theoretical weaknesses of neo-totalitarian thought, which became a "mainstream" interpretation in Eastern Europe after the collapse of Communist rule. While the Communist regimes used antifascist struggle as an integral part of their legitimizing ideologies, Holocaust was effectively silenced in these countries, and all victims were seen as victims of fascism. After the change of regimes, there was a de-tabooization of the topic in both Hungary and Slovakia, and a lot of quality research has been published, which utilized the newly discovered archival sources, which have become accessible to the researchers. Extensive oral history projects have been conducted, Holocaust museums were founded, and new diaries, memoirs and other ego-documents have been published - alongside an impressive number of monographs, analytical works and case studies. The research outcomes became available to different audiences, including pupils and students in school education: e.g. Holocaust is taught as an independent course at Eötvös Loránd University of Budapest as well as in Šafárik University in Košice.

All these results should be mentioned as positive outcomes of the politics of memory after 1989. Yet, however, there are visible tendencies in both societies, presently also greatly fuelled by extreme-right parties and easily channeled by social media, which contribute to the rise of anti-Semitism in both Slovakia and Hungary, as a way of coping with social and political frustration of the majority society. This obviously calls for a more serious approach to the topic of the remembrance of the Holocaust ${ }^{46}$ and imagining the Others on the state levels. We introduced some major historical debates in both countries, which are eventually focused on the relativization of the Holocaust. Without deciding the debates, we would only like to add that many people in the contemporary Slovakia and Hungary decide to deny everything, which has been regarded as "common knowledge" because they think that then they should face the responsibility and crimes of their grandfathers and great-grandfathers. The suffering under Fascism is measured against the suffering under Communism as if the latter, indeed, would counterbalance (or outweigh) the tragedy of the victims of Fascism. Such arguments are fundamentally wrong. What is at stake is not who suffered more but rather the historical understanding of the many factors that led to the

46 See in this respect the article of Moishe POSTONE on the German politics of memory, which is even today relevant: Anti-Semitism and National Socialism. Notes on the German Reaction to "Holocaust", in: New German Critique, 1980, 19, Special Issue 1, 97-115. 
dispossession and eventually to the deportation of hundreds of thousands of Hungarian and Slovakian Jews - with the assistance of the local authorities. The Western example of the formation of a national collective memory, which is conscious of its own history, should be indeed more observed in Eastern Europe in order to go beyond national sensitivities and national traumas (which is often translated as "we have suffered a lot, too") and understand our common history from a global point of view.

\section{References}

ALY, Götz - GERLACH, Christian: Az utolsó fejezet: A magyar zsidók legyilkolása, Budapest 2005. ARENDT, Hannah: The Concentration Camps, in: The Partisan Review, 15, 1948, 7, 747.

BARTHA, Eszter: A sztálinizmus a régi és új historiográfiában: A jelenség meghatározásának elméleti és módszertani problémái, in: A sztálinizmus hétköznapjai: tanulmányok és dokumentumok a Sztálin-korszak történetéböl, KRAUSZ, Tamás (ed.), Budapest 2003, 15-39.

BARTHA, Eszter: Ma már nincsenek evidenciák...Hatalom és emlékezetpolitika - van-e alternatíva? Interjú Krausz Tamással, in: Kritika, 46, 2016, November-December, 10-13.

FÁBRY, Adam (ed.): From the Vanguard to the Margins: Workers in Hungary, 1939 to the Present. Selected Essays by Mark Pittaway, Leiden - Boston 2014.

FITZPATRICK, Sheila: Revisionism in Soviet History, in: History and Theory, 46, 2007, 4, 77-91.

FITZPATRICK, Sheila - GEYER, Michael (eds.): Beyond Totalitarianism: Stalinism and Nazism Compared, New York 2009.

FÓRIS, Ákos: "A zsidók agyonlövése a megszállt területeken köztudomású": Hírek a megszállt keleti területeken elkövetett tömeggyilkosságokról a magyar polgári szerveknél, in: Eszmélet, 29, 2017, 115, 201-211.

GETTY, J. Arch: Origins of the Great Purges: The Soviet Communist Party Reconsidered 1933-1938, Cambridge 1985.

GÉMESI, Ferenc (ed.): A magyar megszállás-vajúdó nemzeti önismeret: válasz a kritikákra, Budapest 2013.

GLEASON, Abbott: Totalitarianism: The Inner History of the Cold War, New York - Oxford 1995.

GOLDMAN, Wendy Z.: Inventing the Enemy: Denunciation and Terror in Stalin's Russia, Cambridge 2011.

HEIMER, György interviews Christian Hartmann, in: Népszabadság, 12 January 2014.

KAMENEC, Ivan: Fenomén holokaustu v historiografii, v umeleckej tvorbe a vo vedomí slovenskej spoločnosti, in: Holokaust ako historický a morálny problém $v$ minulosti a v súčasnosti, Bratislava 2008, 111-117.

KRAUSZ, Tamás: A Gulag aktualitása, in: Gulag: A szovjet táborrendszer története, KRAUSZ, Tamás (ed.), Budapest 2001, 13-26.

KRAUSZ, Tamás (ed.): Az ismeretlen fekete könyv, Budapest 2005.

KRAUSZ, Tamás: The Soviet and Hungarian Holocausts: A Comparative Essay, Boulder (Colorado) 2006.

KRAUSZ, Tamás: Reconstructing Lenin: An Intellectual Biography, New York 2015. 
KRAUSZ, Tamás: "Úriember" megszállók és "jogtipró" partizánok? A magyar megszálló csapatok népirtó tevékenysége Ungváry értelmezésében, in: Eszmélet, 28, 2016, 109, 151-173.

KRAUSZ, Tamás - BARTHA, Eszter (eds.): Holokauszt: Történelem és emlékezet, Budapest 2006.

KRAUSZ, Tamás - BARTA, Tamás (eds.): Az antiszemitizmus történeti formái a cári birodalomban és a Szovjetunió területein, Budapest 2014.

KRAUSZ, Tamás - VARGA, Éva Mária (eds.): A magyar megszálló csapatok a Szovjetunióban. Levéltári dokumentumok 1941-1947, Budapest 2013.

LYNNE, Viola: The Cold War in American Soviet Historiography and the End of the Soviet Union, in: The Russian Review, 61, 2002, 1, 25-34.

MIGAŠOVÁ, Jana: Ironická naivnost' medzivojnových obrazov Generácie 1909, in: Kapitoly k dejinám estetiky na Slovensku V, Prešov 2013, 140-166.

NIŽŇANSKÝ, Eduard: Slovenská historiografia v 90. rokoch 20. storočia o holokauste, in: Historický časopis, 52, 2004, 2, 317-330.

PAULOVIČOVÁ, Nina: The "UmasterablePast"? The Reception of the Holocaust in Postcommunist Slovakia, in: Bringing the Dark Past to Light: The Reception of the Holocaust in Post-Communist Europe, MICHLIC, Joanna - HIMKA, John-Paul (eds.), Lincoln 2013, 549-590.

PEKÁR, Martin: Príbeh Juraja Szánta. Rozhovor o záchrancoch a obeti, Košice 2018.

POSTONE, Moishe: Anti-Semitism and National Socialism. Notes on the German Reaction to "Holocaust", in: New German Critique, 1980, 19, Special Issue 1, 97-115.

ROBERTS, Geoffrey: Stalin's Wars: From World War to Cold War, 1939-1953, New Haven - London 2006.

The Response of Slovak Historians to M. S. Durica's Book: A History of Slovakia and the Slovaks', originally published in the Práca daily, 19 April 1997, English version online: http://www.angelfire.com/hi/xcampaign/praca.html (Downloaded 20 November 2017).

THURSTON, Robert: Life and Terror in Stalin's Russia 1934-1941, New Haven 1996.

TROEBST, Stefan: Holodomor oder Holocaust?, in: FAZ, 2005, 152, 4 July.

UNGVÁRY, Krisztián: Üllő és simogatás között. Válasz Krausz Tamásnak, in: Századok, 148, 2014, 1, 229-233.

UNGVÁRY, Krisztián: A Magyar megszálló csapatok a Szovjetunióban, 1941-1944: esemény, elbeszélés, utóélet, Budapest 2015.

VRZGULOVÁ, Monika (ed.): We saw the Holocaust, Bratislava 2002.

VRZGULOVÁ, Monika: Nevyrozprávané susedské histórie, Bratislava 2017.

\section{Authors}

doc. Dr. Eszter Bartha, M.A., PhD.

Történeti Intézet, Bölcsészettudományi Kar, Eötvös Loránd Tudományegyetem

Historical Institute, Faculty of Humanities, Eötvös Loránd University

Múzeum krt. 4, 1088 Budapest, Hungary

barthaeszter@hotmail.com 
doc. PhDr. Slávka Otčenášová, M.A., PhD.

Filozofická fakulta, Univerzita Pavla Jozefa Šafárika v Košiciach

Faculty of Arts, Pavol Jozef Šafárik University in Košice

Šrobárova 1014/2, 04001 Košice, Slovak Republic

otcenasova@gmail.com 